\title{
Aortaaneurisme hos en ung kvinne
}
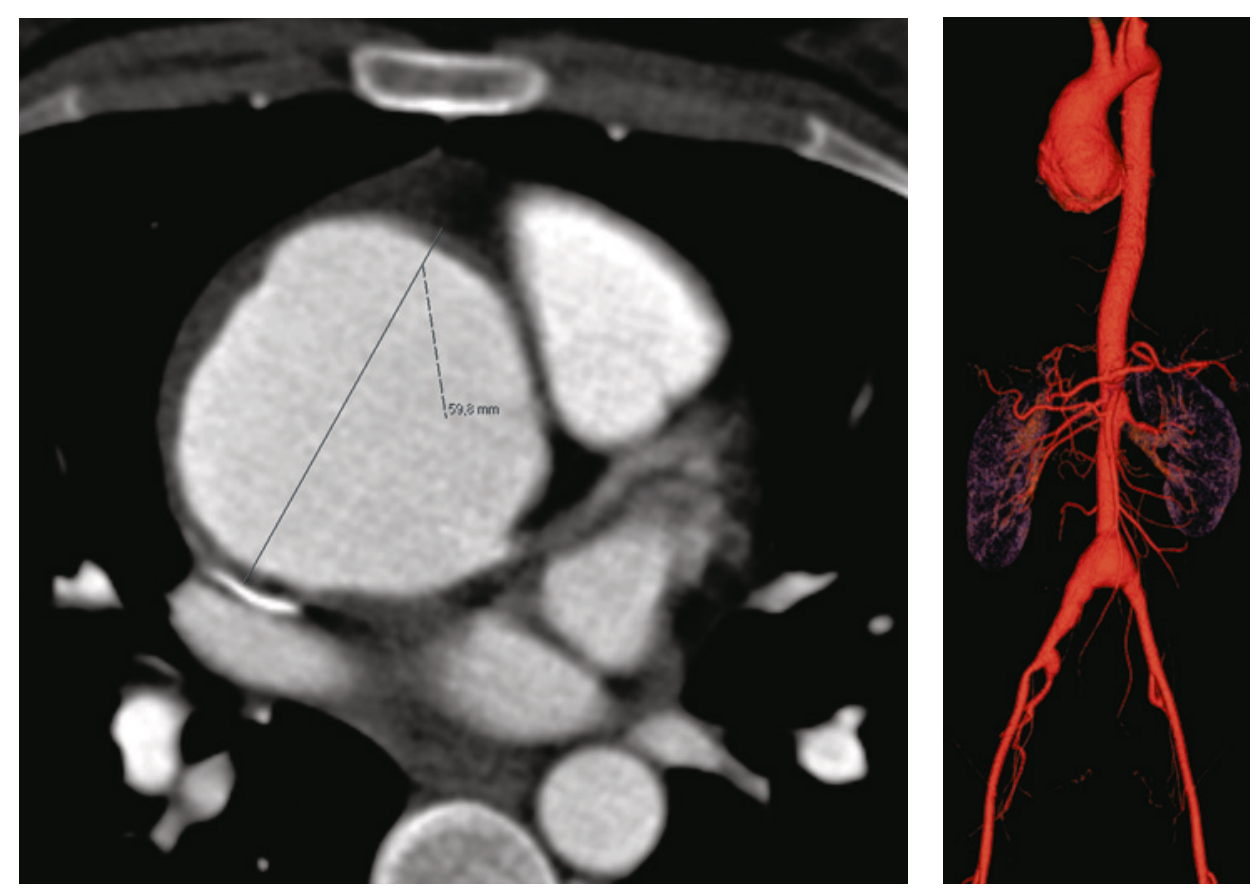

På sesjon fant man hos en 18 år gammel kvinne en diastolisk kardial bilyd. Hun var tidligere frisk og hadde ikke hatt kardiopulmonale symptomer. Undersøkelse med ekkokardiografi, CT-angiografi og MR-angiografi viste en utvidelse av aorta ascendens, med største diameter $46 \mathrm{~mm}$.

Ved kontroll ett år senere hadde pasienten utviklet en asymptomatisk moderat aortainsuffisiens. CT-angiografi viste at aneurismet $\mathrm{i}$ aorta ascendens nå hadde økt til $60 \mathrm{~mm}$, som vist på bildet til venstre. I tillegg avdekket man aneurismer i venstre a. subclavia, aortabifurkaturen og høyre a. iliaca interna. Aneurismene ses på bildet til høyre, en 3Drekonstruksjon av CT-angiografien (video). Det ble også påvist lett veggfortykkelse i aorta ascendens, noe som er et tegn på inflammasjon. Pasienten ble operert med reseksjon og rekonstruksjon av aorta ascendens med innsetting av aortaprotese. Biopsi av karveggen viste kronisk arteritt, best forenlig med Takayasus arteritt.

Takayasus arteritt er en kronisk storkarvaskulitt som vanligvis rammer kvinner under 40 år (1). Aorta og dens avgangskar er oftest affisert. Akutt inflammasjon i karveggen ses som fortykkelse av denne med kontrastoppladning på CT og MR. På lengre sikt kan dette resultere i stenotiske partier eller aneurismer. Som oftest er det allmennsymptomer som feber, vekttap, nattesvette og utmattelse (fatigue), i tillegg til smerter grunnet iskemi. Senkning og CRP-nivå er vanligvis forhøyet (1). Sykdommen er kronisk. Utvikling av hjerteklaffinsuffisiens eller aneurismer gir en dårligere prognose. Vår pasient hadde lett forhøyet CRP-nivå preoperativt, men ingen allmennsymptomer.

Ved revmatologisk avdeling ble det startet behandling med prednisolon og metotreksat. Pasienten er nå $\mathrm{i}$ god form og følges med regelmessige kontroller.

Pasienten har gitt samtykke til at artikkelen blir publisert.

\section{Agnete Malm Gulati}

agnete.malm.gulati@stolav.no

Revmatologisk avdeling

\section{Asbjørn Ødegård}

Klinikk for bildediagnostikk

St. Olavs hospital
Agnete Malm Gulati (f. 1981) er lege i spesialisering i revmatologi.

Forfatter har fylt ut ICMJE-skjemaet og oppgir ingen interessekonflikter.

Asbjørn Ødegård (f. 1961) er overlege i radiologi.

Forfatter har fylt ut ICMJE-skjemaet og oppgir ingen interessekonflikter.

\section{Litteratur}

1. Chatterjee S, Flamm SD, Tan CD et al. Clinical diagnosis and management of large vessel vasculitis: Takayasu arteritis. Curr Cardiol Rep 2014 16: 499.

Mottatt 16.9. 2014, første revisjon innsendt 2.11. 2014, godkjent 10.11. 2014. Redaktør: Hanne Støre Valeur.

Video på www.tidsskriftet.no 